\title{
FORMULASI SEDIAAN BALSEM DARI EKSTRAK DAUN KEMANGI (Ocimum SanctumLinn) DAN PEMANFAATANNYA SEBAGAI OBAT TRADISIONAL
}

\author{
Wahyuddin Jumardin, Safaruddin Amin, Nurhidayati M.Syahdan \\ Sekolah Tinggi Ilmu Kesehatan Mega Rezky Makassar \\ Email : wandy271185@gmail.com
}

\begin{abstract}
The research has conducted to produce balm basil leaf extract which aims to discover how to formulating preparations balm from basil leaf extract (Ocimum sanctum Linn) as a tradisional medicine. The results of research that basil leaf extract can be made in the preparation as a balm. This is indicated through organoleoptic observation and the homogeneity of the preparation is stable.
\end{abstract}

Key word : Basil Leaf (latin), Traditional medicine, Formulation and Balm.

\section{PENDAHULUAN}

Keanekaragaman hayati yang ada dibumi ini tidak hanya digunakan sebagai bahan pangan ataupun untuk dinikmati keindahannya saja, namun bermanfaat juga sebagai bahan untuk pengobatan berbagai penyakit. Tanaman yang ada terutama yang tumbuh di Indonesia dikenal sebagai bahan yang efektif untuk obat dan digunakan sebagai bahan baku industri obat indonesia selain sebagai obat tradisional. Berbagai varietas kemangi telah banyak dikenal didunia dan biasanya diseleksi didasarkan pada aroma dan warna tanaman. Tanaman ini diketahui berasal dari daerah tropis Asia dan kepulauan di daerah pasifik. Pertama kali ditemukan dan diolah di india. Kini, tanaman ini tersebar luas di Asia, Afrika, Amerika Tengah dan selatan. Secara komersial banyak dibudidayakan di Eropa bagian Selatan, Mesir, Maroko, Indonesia dan California. (Kurniasi. 2014).

Di Indonesia, tanaman kemangi banyak ditemukan di daerah Sumatra, Jawa dan Maluku. Namun, banyak di budidayakan didaerah Jawa Barat untuk dicari kandungan minyak atsirinya yang dapat membuat tubuh lebih segar dan meringankan rasa sakit. Minyak atsiri tersebut sering digunakan sebagai minyak pijat aroma. (Soedarso.2012).

Penelitian ini sebelumnya telah dilakukan oleh Maria Dolfiana Ngepi dari akademi farmasi indonesia putra malang pada tahun 2009 dengan judul Pemanfaatan minyak atsiri dari daun 
Formulasi Sediaan Balsem Dari Ekstrak Daun Kemangi (Ocimum SanctumLinn) Dan Pemanfaatannya Sebagai Obat Tradisional

cengkeh (Caryophili Folium) sebagai obat tradisional dengan menggunakan destilasi uap air dan menghasilkan minyak atsiri daun cengkeh diperoleh dari hasil destilasi, berupa minyak yang berwarna kuning pucat dan aroma khas cengkeh. Daun cengkeh kering sebanyak $2,5 \mathrm{~kg}$ setelah didestilasi diperoleh sebanyak $15 \mathrm{ml}$ minyak atsiri. (Maria Dolfiana Ngepi. 2009).

Kemangi adalah tumbuhtumbuhan yang hidup secara liar dan berbau harum. Tanaman ini tumbuh dengan baik di dataran rendah sampai dataran tinggi. Kemangi sangat sensitif terhadap iklim dingin, dapat berkembang dengan sangat baik jika mendapat sinar matahari yang melimpah dan membutuhkan iklim yang panas dan ringan. Sedangkan, untuk memperbanyak tanaman kemangi, dapat diperbanyak dengan biji. (Kurniasih. 2014).

Sehubungan dengan hal diatas, untuk mengoptimalkan pemanfaatan daun kemangi tersebut, maka diolah dengan metode maserasi dan diambil ekstraknya. Ekstrak yang diperoleh akan dibuat dalam bentuk sediaan balsem, yang pada dasarnya merupakan suatu sediaan salep. Berdasarkan farmakope Indonesia salep, unguentum adalah sediaan setengah padat yang mudah dioleskan dan digunakan sebagai obat luar. Bahan obatnya harus larut atau terdispersi homogen dalam dasar salep yang cocok, (FI ED III 1979:33).

Dalam hal ekstrak daun kemangi dibuat suatu sediaan topikal yang dioleskan pada kulit yaitu balsem. Bentuk sediaan balsem atau salep lebih dipilih karena penggunaanya sangat mudah. Untuk mengetahui formulasi yang baik dalam pembuatan balsem ekstrak daun kemangi, bahan aktif harus larut dalam basis salep sehingga dapat diketahui sediaan balsem daun kemangi tersebut dapat menghasilkan mutu fisik yang baik. Berdasarkan hal tersebut penelitian dilakukan untuk mengetahui apakah pemanfaatan daun kemangi yang diolah dengan metode maserasi dan kemudian dibuat dalam bentuk sediaan balsem dapat menghasilkan mutu fisik balsem yang sesuai dengan standar yang telah ditetapkan berdasarkan evaluasi-evaluasi terhadap balsem yaitu organoleptis (bentuk, warna dan bau), dan uji homogenitas. Selain melakukan evaluasi tersebut juga dilakukan uji volunter, uji volunter ini dilakukan untuk mengetahui pendapat masyarakat mengenai mutu fisik dari 
Formulasi Sediaan Balsem Dari Ekstrak Daun Kemangi (Ocimum SanctumLinn) Dan Pemanfaatannya Sebagai Obat Tradisional

sediaan balsem ekstrak daun kemangi yang sudah dibuat.

\section{METODE PENELITIAN}

Metode yang akan digunakan adalah metode maserasi. Maserasi ini dilakukan dengan cara merendam serbuk simplisia dalam cairan penyari yang mengandung zat aktif yang mudah larut dalam cairan penyari Kemudian perendaman simplisia tersebut menggunakan etanol $70 \%$ selama 24 jam. Perendaman dilakukan selama kurun waktu tertentu, misalnya dilakukan selama 24 jam dengan diberikan pengadukan setiap 1-2 jam (kalau malam biarkan saja tidak perlu diaduk), setelah 24 jam ganti pelarut dengan pelarut baru dan selanjutnya perlakukan sama dengan yang pertama. Penggantian pelarut dilakukan untuk mempercepat proses ekstraksi, karena pelarut pertama mungkin sudah jenuh oleh senyawa sehingga tidak dapat melarutkan kembali senyawa yang diharapkan, dan waktu penggantian tergantung kebutuhan tidak harus 24 jam.

\section{Alat dan Bahan}

Alat yang digunakan adalah stampler, pipet tetes, sendok tanduk, neraca, gegep, cawan porselin, gelas ukur, batang pengaduk, aluminium foil, kertas saring, dan tissue.

Bahan yang digunakan yaitu ekstrak daun kemangi, vaselin album, menthol, ol. Menthae, paraffin liquidum, aluminium foil, kertas saring, dan tissue.

\section{Pembuatan balsam}

Timbang semua bahan yang ada yaitu paraffin liq, vaselin album, menthol dan ol. Menthae kemudian leburkan diatas penangas air, setelah semua bahan sudah lebur, ekstrak daun kemangi dihitung dan tambahkan masing-masing ekstrak daun kemangi kedalam balsem sebanyak 3\%, $7 \%$ dan $9 \%$ kemudian aduk sampai homogen dan biarkan hingga dingin dan masukkan kedalam wadah yang sudah tersedia.

\section{Rancangan formula}

\begin{tabular}{lccccc}
\hline \multirow{2}{*}{ No } & \multirow{2}{*}{ Nama bahan } & \multicolumn{4}{c}{ Konsentrasi } \\
\cline { 3 - 6 } & & Basis/ F I & F II & F III & F IV \\
\hline 1. & Ekstrak Ocimum & - & $3 \%$ & $7 \%$ & $9 \%$ \\
2. & Paraffin. liq & $8 \mathrm{~g}$ & $8 \mathrm{~g}$ & $8 \mathrm{~g}$ & $8 \mathrm{~g}$ \\
3. & Menthol & $6 \mathrm{~g}$ & $6 \mathrm{~g}$ & $6 \mathrm{~g}$ & $6 \mathrm{~g}$ \\
4. & Ol. menthae & $6 \mathrm{~g}$ & $6 \mathrm{~g}$ & $6 \mathrm{~g}$ & $6 \mathrm{~g}$ \\
5. & Vaselin album & $20 \mathrm{~g}$ & $20 \mathrm{~g}$ & $20 \mathrm{~g}$ & $20 \mathrm{~g}$ \\
\hline
\end{tabular}


Formulasi Sediaan Balsem Dari Ekstrak Daun Kemangi (Ocimum SanctumLinn) Dan Pemanfaatannya Sebagai Obat Tradisional

HASIL PENELITIAN

Tabel 1. Komposisi Bahan Formula Balsem

\begin{tabular}{clcccc}
\hline \multirow{2}{*}{ NO } & \multicolumn{1}{c}{ BAHAN } & \multicolumn{4}{c}{ FORMULA } \\
\cline { 2 - 5 } & Basis/ F I & F II & F III & F IV \\
\hline 1. & Ekstrak daun kemangi & - & $3 \%$ & $7 \%$ & $9 \%$ \\
2. & Paraffin liquid & $8 \mathrm{~g}$ & $8 \mathrm{~g}$ & $8 \mathrm{~g}$ & $8 \mathrm{~g}$ \\
3. & Menthol & $6 \mathrm{~g}$ & $6 \mathrm{~g}$ & $6 \mathrm{~g}$ & $6 \mathrm{~g}$ \\
4. & Ol. Menthae & $6 \mathrm{~g}$ & $6 \mathrm{~g}$ & $6 \mathrm{~g}$ & $6 \mathrm{~g}$ \\
5. & Vaselin album & $20 \mathrm{~g}$ & $20 \mathrm{~g}$ & $20 \mathrm{~g}$ & $20 \mathrm{~g}$ \\
\hline
\end{tabular}

Tabel 2. Hasil Pengamatan Organoleptis Balsem Kemangi

\begin{tabular}{cccc}
\hline Formula & Warna & Tekstur & Bau /aroma \\
\hline I & Hijau & Setengah padat & kemangi, kurang tajam \\
II & Hijau toska & Setengah padat & Kemangi, kurang tajam \\
III & Hijau tua & Setengah padat & Kemangi, tajam \\
\hline
\end{tabular}

Tabel 3. Hasil Uji Homogenitas Balsem ekstrak Daun Kemangi

\begin{tabular}{cc}
\hline Formula & Homogenitas \\
\hline II & Homogen \\
III & Homogen \\
\hline
\end{tabular}

\section{PEMBAHASAN}

Pada penelitian ini telah dilakukan pengambilan ekstrak terhadap daun kemangi dengan menggunakan metode maserasi. Penelitian ini bertujuan untuk memanfaatkan daun kemangi yang belum dimanfaatkan secara optimal. Pemilihan metode maserasi ini karena dengan metode ini digunakan untuk menyari simplisia yang mengandung komonen kimia yang mudah larut dalam cairan penyari. Dan keuntungan dari metode ini adalah peralatannya sederhana yang mampu menarik senyawa kimia yang sifatnya polar. Maserasi ini dilakukan dengan cara merendam serbuk simplisia dalam cairan penyari yang mengandung zat aktif yang mudah larut dalam cairan penyari. Keuntungan cara penyari dengan maserasi adalah cara pengerjaan dan peralatan yang sederhana dan mudah diusahakan, unit alat yang dipakai sederhana, prosesnya relatif hemat penyari, tanpa pemanasan. Sedangkan kerugian dari metode ini adalah pengerjaan lama dan penyariannya kurang sempurna.

Kemudian

perendaman simplisia tersebut menggunakan etanol $70 \%$ selama 24 jam. Perendaman dilakukan selama kurun waktu tertentu, misalnya dilakukan selama 24 jam 
Formulasi Sediaan Balsem Dari Ekstrak Daun Kemangi (Ocimum SanctumLinn) Dan Pemanfaatannya Sebagai Obat Tradisional

dengan diberikan pengadukan setiap 1-2 jam (kalau malam biarkan saja tidak perlu diaduk), setelah 24 jam ganti pelarut dengan pelarut baru dan selanjutnya perlakukan sama dengan yang pertama. Penggantian pelarut dilakukan untuk mempercepat proses ekstraksi, karena pelarut pertama mungkin sudah jenuh oleh senyawa sehingga tidak dapat melarutkan kembali senyawa yang diharapkan, dan waktu penggantian tergantung kebutuhan tidak harus 24 jam. Penggantian pelarut dihentikan bila pelarut terakhir setelah didiamkan seperti pelarut sebelumnya memperlihatkan warna asli pelarut yang menandakan senyawa sudah terekstraksi seluruhnya. Ekstrak daun kemangi yang diperoleh lalu diuji organoleptis dan uji volunter kepada responden hal ini untuk menentukan mutu dan khas kemangi. Hasil uji organoleptis, ekstrak tersebut berwarnah hijau tua dengan aroma khas kemangi, rendeman $500 \mathrm{~g}$ dan ekstrak $25 \mathrm{~g}$ ( v/v). Ekstrak yang telah didapatkan akan digunakan sebagai bahan aktif dalam pembuatan balsem dengan penambahan jumlah ekstrak yang berbeda pada formula I,II, dan III. Hal ini bertujuan untuk mengetahui pada formula mana yang lebih disukai oleh responden yang dilakukan dengan uji volunter, melalui bertanya langsung kepada masyarakat mengenai sediaan balsem tersebut. Pembuatan balsem dilakukan dengan cara melebur basis balsem yakni vaselin album hingga lebur kemudian panaskan lumpang lalu masukkan mentol ke dalam lumpang panas lalu masukkan ekstrak masing-masing konsentrasi, hal ini bertujuan agar ekstrak tersebut dapat menyatu dengan bahan lainnya.

Dari hasil uji homogenitas menunjukan bahwa ketiga formula sediaan balsem tersebut homogen karena tidak terdapat serbuk -serbuk kasar atau kotoran dan juga bahan aktif yakni ekstrak daun kemangi tersebut tersebar secara merata dalam basisi balsem. Setelah diuji organoleptis dan homogenitasnya balsem kemangi tersebut diujikan kepada responden untuk mengetahui formula mana yang lebih disukai dan diterima oleh responden. Persentase jawaban responden terhadap balsem kemangi formula I, II, dan III adalah (58\%), (68,75\%), dan (84,75\%). Perbedaan porsentase hasil uji volunter tersebut menunjukan bahwa formula III lebih disukai oleh responden hal ini dikarenakan pada formula ini penambahan ekstrak daun kemangi lebih banyak yaitu $9 \%$ 
Formulasi Sediaan Balsem Dari Ekstrak Daun Kemangi (Ocimum SanctumLinn) Dan Pemanfaatannya Sebagai Obat Tradisional

dibanding pada formula I dan II, yakni

\section{DAFTAR PUSTAKA}

$3 \%$ dan $7 \%$ sehingga balsem formula

III juga lebih terasa aroma yang lebih tajam, dibanding formula I, dan I.

\section{KESIMPULAN}

Dari hasil penelitian dapat

disimpulkan bahwa formulasi ekstrak daun kemangi (Ocimum sanctum Linn) dapat diformulasikan dalam bentuk sediaan balsam.

Indonesia. 1995. Farmakope Indonesia Edisi IV. Jakarta : Departemen Kesehatan Indonesia.

Kurniasih.2014, Khasiat dahsyat kemangi, Yogyakarta ; pustaka baru press.

Maria Dolfiana Ngepi. 2009, Pemanfaatan minyak atsiri dari daun cengkeh (Caryophilli folium) sebagai obat tradisional dalam bentuk sediaan balsem.

Soedarso.2012, Kemangi daun sakti penjaga perut, surabaya ; stomata. 